Mеталлофиз. новейшие технол. / Metallofiz. Noveishie Tekhnol. (C) 2016 ИМФ (Институт металлофизики 2016, т. 38, № 5, сc. 657-668 / DOI: 10.15407/mfint.38.05.0657 им. Г. В. Курдюмова НАН Украины) Оттиски доступны непосредственно от издателя

Фотокопирование разрешено только

Напечатано в Украине.

в соответствии с лицензией

PACSnumbers: 72.80.Tm, 77.22.Ch, 78.70.Gq, 81.05.U-, 81.07.De, 81.07.Pr, 82.35.Np

\title{
Microwave Properties and Conductivity Anisotropy of Oriented Multiwalled Carbon Nanotube/Epoxy Composites
}

\author{
L. L. Vovchenko, V. V. Zagorodnii", O. S. Yakovenko, L. Yu. Matzui, \\ V. V. Oliynyk*, and V. L. Launets*
}

Taras Shevchenko National University of Kyiv, Department of Physics, 64/13 Volodymyrska Ave., 01601 Kyiv, Ukraine

"Taras Shevchenko National University of Kyiv, Department of Radiophysics, Electronics, and Computer Systems, 64/13 Volodymyrska Ave., 01601 Kyiv, Ukraine

Epoxy composites with the aligned network of multiwalled carbon nanotubes generated by applying AC electric field during the curing process are fabricated. Industrial nanotubes with diameter of 10-30 nm and length of 10-30 $\mu \mathrm{m}$ are used. The nanotubes' concentration is varied from 0.2 to $1.0 \% \mathrm{wt}$. DC conductivity is measured for two orientations of multiwalled carbon nanotubes' network - parallel and perpendicular to the direction of the instrument current. Similarly, complex microwave permittivity and conductivity are investigated for parallel and perpendicular orientations of multiwalled carbon nanotubes' network to the microwave electric field. Measured DC conductivity of order of $10^{-7}-10^{-5} \mathrm{~S} / \mathrm{m}$ contrasts with microwave conductivity of order of $10^{-2}-10^{-1} \mathrm{~S} / \mathrm{m}$. The conductivity anisotropy varies from 18 to 26 for DC measurements and from 1.26 to 2.04 for microwave ones. Such difference in anisotropies can be attributed to the essential inequality of the actual electron transport mechanisms under DC and microwave electric fields.

Key words: carbon nanotubes, polymer composites, DC conductivity, anisotropy, dielectric permittivity, absorption loss.

Corresponding author: Lyudmyla Leonidivna Vovchenko

E-mail:vovch@univ.kiev.ua

Please cite this article as: L. L. Vovchenko, V. V. Zagorodnii, O. S. Yakovenko, L. Yu. Matzui, V. V. Oliynyk, and V. L. Launets, Microwave Properties and Conductivity Anisotropy of Oriented Multiwalled Carbon Nanotube/Epoxy Composites, Metallofiz. Noveishie Tekhnol., 38, No. 5: 657-668 (2016), DOI: 10.15407/mfint.38.05.0657. 
Було виготовлено епоксидні композити з орієнтованими багатошаровими вуглецевими нанотрубками із застосуванням змінного електричного поля в процесі твердіння композитів. Було використано промислові вуглецеві нанотрубки з зовнішнім діяметром 10-30 нм та довжиною 10-30 мкм. Концентрація нанотрубок варіювалася від 0,2 до 1,0\% ваг. Електропровідність на постійному струмі було виміряно для двох орієнтацій багатошарових вуглецевих нанотрубок відносно напрямку електричного струму: паралельної та перпендикулярної. Так само, комплексну діелектричну проникність та електропровідність у мікрохвильовому діяпазоні було досліджено при паралельній та перпендикулярній орієнтаціях багатошарових вуглецевих нанотрубок у композиті відносно вектора електричного поля мікрохвильового випромінення. Виміряна на постійному струмі електропровідність порядку $10^{-7}-10^{-5} \mathrm{Cm} / \mathrm{м}$ значно відрізняється від мікрохвильової електропровідности, яка є порядку $10^{-2}-10^{-1} \mathrm{Cm} / \mathrm{M}$. Анізотропія електропровідности змінюється від 18 до 26 при вимірюваннях на постійному струмі та від 1,26 до 2,04 для мікрохвильових вимірювань. Така ріжниця в анізотропії електропровідности може бути пов'язана 3 суттєвою ріжницею в механізмах електротранспорту при дії постійного електричного поля та змінного електричного поля мікрохвильового випромінення.

Ключові слова: вуглецеві нанотрубки, полімерні композити, електропровідність на постійному струмі, анізотропія, діелектрична проникність, втрати на поглинання.

Были изготовлены эпоксидные композиты с ориентированными многослойными углеродными нанотрубками с применением переменного электрического поля в процессе отвердения композитов. Были использованы промышленные углеродные нанотрубки с внешним диаметром 10-30 нм и длиной 10-30 мкм. Концентрация нанотрубок варьировалась от 0,2 до $1,0 \%$ вес. Электропроводность на постоянном токе была измерена для двух ориентаций многослойных углеродных нанотрубок относительно направления электрического тока: параллельной и перпендикулярной. Точно так же, комплексная диэлектрическая проницаемость и электропроводность в микроволновом диапазоне были исследованы при параллельной и перпендикулярной ориентациях многослойных углеродных нанотрубок в композите относительно вектора электрического поля микроволнового излучения. Измеренная на постоянном токе электропроводность порядка $10^{-7}-10^{-5} \mathrm{Cm} /$ м значительно отличается от микроволновой электропроводности, которая составляет порядка $10^{-2}-10^{-1} \mathrm{Cm} / \mathrm{м}$. Анизотропия электропроводности изменяется от 18 до 26 при измерениях на постоянном токе и от 1,26 до 2,04 для микроволновых измерений. Такие различия в анизотропии электропроводности могут быть связаны с существенными различиями в механизмах электротранспорта при действии постоянного электрического поля и переменного электрического поля микроволнового излучения.

Ключевые слова: углеродные нанотрубки, полимерные композиты, электропроводность на постоянном токе, анизотропия, диэлектрическая проницаемость, потери на поглощение. 


\section{INTRODUCTION}

Polymer materials have been replacing metals for the last half century. Besides structural applications, polymer composites with conductive fillers enable a whole new variety of useful and beneficial applications in electronics, automotive, and aerospace industries [1,2]. Antistatic parts and electromagnetic shielding composites are among growing sectors $[3,4]$.

Conductive fillers such as carbon black and graphite particles provide the necessary polymer conductivity at rather high loading. As a result, the structural properties of the composite are highly degraded. Multiwalled carbon nanotubes (MWCNTs) have high conductivity, high aspect ratio and natural tendency to form bundles; therefore, MWCNTs are promising in providing inherently long conductive pathways even at ultralow loadings [5]. One of actual applications of mentioned materials is efficient electromagnetic shielding at rather low filler concentration.

The conductivity of such composites and the corresponding percolation threshold depend on the type and the aspect ratio of the filler, the filler distribution as well as the concentration [6]. Static and kinetic percolation thresholds in composites with conductive nanosize fillers are essentially different [7]. For composites with low filler concentration, the static threshold is much higher than kinetic one due to the hindered conductive pathway random formation where some fraction of filler is shared between several orders higher amount of the polymer. In addition, the kinetic percolation threshold is lower due to the filler particles movement caused by diffusion, shearing, and external force control. Thus, the composite properties can be different at the same initial ingredients. In this connection, one can increase the composite conductivity by the filler orientation during the polymerization process for the formation of the conductive network in the polymer matrix. Carbon nanotubes as conductive filler with high aspect ratio are feasible objects for this effect.

Several methods of nanotubes alignment are known: mechanical [8], magnetic [9], and electric [10] ones. Mechanical alignment often leads to nanotubes breaking with aspect ratio reduction and percolation threshold shift towards higher filler concentrations. Magnetic alignment requires strong magnetic field for carbon nanotubes because of their low values of magnetic susceptibility $\left(\cong 10^{-6} \mathrm{emu} / \mathrm{g}\right)$. MWCNTs as polymeric pure carbon particles have highly anisotropic physical properties, especially, electrical. Therefore, composite formation under the electric field provides the decrease of the percolation threshold as well as 
anisotropic electrical properties of the fabricated material. While the influence of the viscosity of the medium, the interactions between constituents, and the processing routine are still discussed [11-13], several researchers consider that an alternating electric field is much more efficient for the MWCNTs alignment $[10,14]$.

\section{MATERIAL AND METHODS}

Industrial MWCNTs of $90 \%$ purity (Cheap Tubes Inc.) were synthesized by chemical vapour deposition. The MWCNTs have diameter of $10-30 \mathrm{~nm}$ and length of $10-30 \mu \mathrm{m}$, thus the aspect ratio ranges within 300-3000. MGS L285 epoxy resin with H285 hardening agent (weight mixing ratio $1: 0.4$ ) was used in this study. The specified viscosity of $\mathrm{L} 285$ epoxy is $600-900 \mathrm{mPa} \cdot \mathrm{s}$ at $25^{\circ} \mathrm{C}$ and allows effective electric orientation of MWCNTs in the epoxy during the curing process. This is especially true for low filler concentration. However, we did not consider ultralow MWCNTs concentrations $(0.1 \%$ or less) for the study because of poor microwave response to the composite with low conductivity.

MWCNTs/epoxy mixtures were mechanically stirred and subjected to ultrasonic homogenization at $40 \mathrm{kHz}$ for $15 \mathrm{~min}$. Then, the proper quantity of H285 hardening agent was added, and the mixture was poured to the silicon mould with two copper electrodes. Further composite curing was continued for $1 \mathrm{~h}$ under the applied $15 \mathrm{kHz}$ electric field of $80 \mathrm{kV} / \mathrm{m}$ amplitude. After that, the electric field was removed and the samples were kept at room temperature for full induration. The composite samples were also exposed to heat treatment at stepped temperature to finalize the polymerization process.

The electric field applied to MWCNTs-containing viscous medium induces effective dipoles on the carbon nanotubes because of the difference between the nanotube and the surrounding medium electrical properties. MWCNTs networks formation is stipulated by nanotubes rotation and alignment along the electric field direction due to incipient torque on the nanotube edge $[15,16]$. Mutual attraction of contiguous carbon nanotubes occurs due to the induced dipoles contributing to a lengthwise contact and the formation of aligned structures [17]. The action of AC electric field leads to formation of ranks of nanotube aggregates as it was shown in [18] by in situ optical microscopy investigation.

Other mechanisms of MWCNTs networks formation such as nanotube-to-nanotube Coulombic interaction and nanotubes migration towards an electrode are much less essential at low concentration of nanotubes with aspect ratio of $\sim 10^{3}$ due to the rapid nanotube rotation in comparison with characteristic times of above-mentioned mechanisms [13]. AC electric field also minimizes the nanotubes migration towards an electrode in comparison with DC field. Thus, the MWCNTs 
network formation is determined by the electric field amplitude and frequency, the nanotubes' concentration and aspect ratio, and the viscosity of the composite mixture. The latter increases with the filler content increase and hampers in fabrication of oriented composites with high MWCNTs concentration. For concentrations up to several percent, MGS L285 epoxy is found to be a good experimental polymeric matrix as low viscous and low toxic laminating resin approved for the production of certificated aircraft parts.

The cured composite samples have been additionally processed and polished for further characterization. Cubic shape of $7 \times 7 \times 7 \mathrm{~mm}^{3}$ was given to the samples for DC conductivity measurements. DC conductivity was measured by two probes method. This method is enough sensitive to measure low conductivity up to $10^{-11} \mathrm{~S}$ at constant ambient temperature and the standard clipping pressure. The opposite faces of the composite sample were covered by the conductive silver-containing paste to provide good electric contact with copper measuring probes. The conductivity was measured for two orientations of the instrument current: parallel and perpendicular to the direction of oriented MWCNTs network, which coincides with the direction of processing electric field applied during the composite curing.

The composite samples were also characterized in the microwave frequency range. Complex permittivity was measured in the range of 26.5-53.3 GHz using waveguide method [19]. The composite samples were shaped to fit $\mathrm{Ka}$ band (frequency range is $25.8-37.5 \mathrm{GHz}$; waveguide cross-section $-7.2 \times 3.4 \mathrm{~mm}^{2}$ ) and $U$ band (frequency range is $37.5-53.5 \mathrm{GHz}$; waveguide cross-section $-5.2 \times 2.6 \mathrm{~mm}^{2}$ ) rectangular hollow waveguides. As the electric field of the dominant waveguide mode H10 is transversely polarized to the waveguide axis [20], one can selectively measure the material response to the microwave electric field orienting the preferential direction in the properly shaped specimen parallel or perpendicular to the effective electric field direction.

\section{RESULTS AND DISCUSSION}

We present experimental results on the DC and microwave conductivity of MWCNT/epoxy composites with oriented distribution of filler.

Figure 1 shows the dependences of DC conductivity on MWCNTs concentration in the composite. The conductivity of cured pure epoxies is about $10^{-10} \mathrm{~S} / \mathrm{m}$ with minor variations between samples. For both MWCNTs network orientations, the conductivity rises with the concentration increase up to $0.4 \%$ and recedes at the concentration of $1 \%$. This indicates much lower percolation threshold for test composites in comparison with epoxy composites with disordered MWCNTs distribution [21]. While the measured conductivity $\sigma_{\text {per }}$ of composites with perpendicular orientation of MWCNTs network varies between 0.26 and 


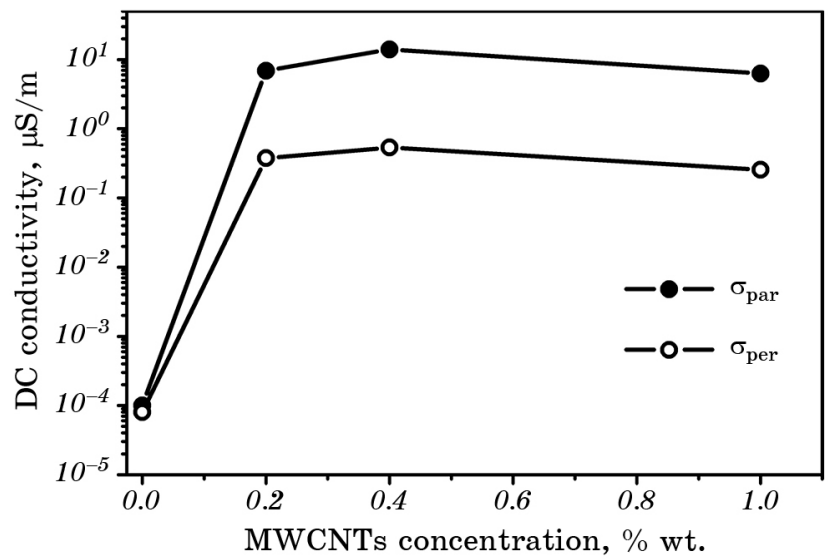

Fig. 1. DC conductivity versus MWCNTs concentration in the composite: $\sigma_{\text {par }}$ for parallel orientation of MWCNTs network to the test current, $\sigma_{\mathrm{per}}$-for perpendicular orientation of MWCNTs network.

$0.53 \mu \mathrm{S} / \mathrm{m}$ for concentrations $0.2-1.0 \%$, the conductivity $\sigma_{\mathrm{par}}$ in the parallel-oriented direction is found to be between 6.3 and $14.0 \mu \mathrm{S} / \mathrm{m}$. Thereafter, the conductivity anisotropy value, calculated as $\sigma_{\mathrm{par}} / \sigma_{\mathrm{per}}$, reaches 26 (Table 1). Sufficiently large DC conductivity anisotropy value confirms the primary parallel-oriented distribution of nanotubes in the volume of the epoxy matrix with inessential nanotube-tonanotube interaction in the transverse direction. This can be used for antistatic-protective parts or conductive-directed paths made of oriented MWCNTs-filled composites with low filler concentration.

The dependences of real part $\varepsilon^{\prime}$ of composite complex microwave permittivity on frequency for different MWCNTs concentration are shown in Fig. 2. For both parallel and perpendicular orientation of MWCNTs with respect to the microwave electric field, the real permittivity increases with the filler concentration increment. The increasing permittivity dependence on frequency for low concentrations changes into decay function for higher concentrations. The actual values of $\varepsilon^{\prime}$ are in the range of 2.45-4.6 for all tested concentrations. The values of the imaginary part $\varepsilon^{\prime \prime}$ of composite complex microwave permittivity also increase with the increase of CNT content, i.e. the absorption losses increase in such composites. The actual values of $\varepsilon^{\prime \prime}$ are

TABLE 1. DC conductivity anisotropy $\sigma_{\mathrm{par}} / \sigma_{\mathrm{per}}$ in oriented MWCNT/epoxy composites at different concentrations.

\begin{tabular}{c|c|c|c}
\hline MWCNTs concentration, \% wt. & 0.2 & 0.4 & 1.0 \\
\hline$\sigma_{\mathrm{par}} / \sigma_{\mathrm{per}}$ & 18.4 & 26.2 & 24.5 \\
\hline
\end{tabular}




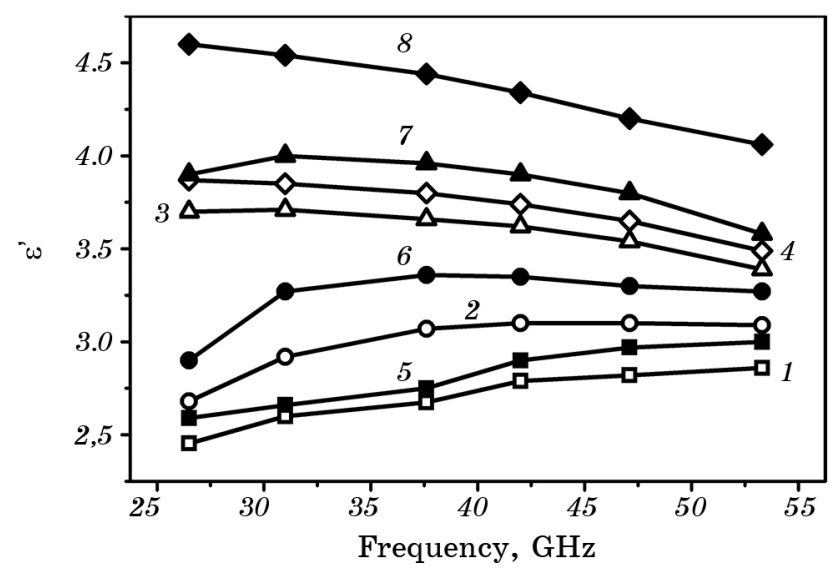

Fig. 2. Real part $\varepsilon^{\prime}$ of composite complex microwave permittivity versus frequency for different MWCNTs orientation to the microwave electric field and different concentration: 1, 2, 3, 4-perpendicular orientation and concentrations $0,0.2,0.4$ and $1.0 \%$ wt., respectively; $5,6,7,8$-parallel orientation and concentrations $0,0.2,0.4$ and $1.0 \%$ wt., respectively.

in the range of $0.1-1$ for tested MWCNTs concentrations.

Figure 3 represents the data on dielectric loss tangent $\operatorname{tg} \delta=\varepsilon^{\prime \prime} / \varepsilon^{\prime}$ for the epoxy composites with aligned MWCNTs. The maximum dielectric loss tangent of 0.16 for perpendicular MWCNTs orientation and 0.22 for parallel orientation are measured at $26.5 \mathrm{GHz}$ (the lowest frequen-

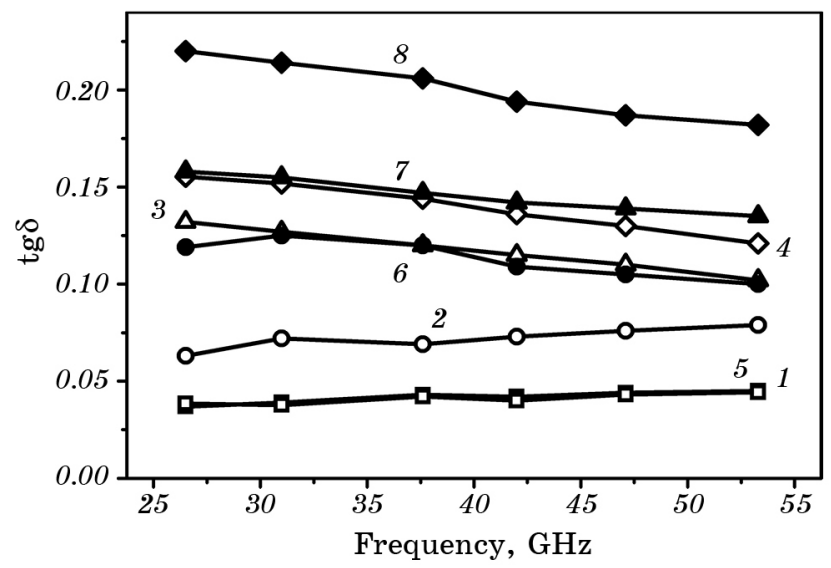

Fig. 3. Dielectric loss tangent $\operatorname{tg} \delta$ of composites versus frequency for different MWCNTs orientation to the microwave electric field and different concentration: $1,2,3,4$-perpendicular orientation and concentrations $0,0.2,0.4$ and $1.0 \%$ wt., respectively; $5,6,7,8$-parallel orientation and concentrations 0 , $0.2,0.4$ and $1.0 \%$ wt., respectively. 
cy in the test range).

Experimental data on microwave $\varepsilon^{\prime \prime}$ in a lossy medium can be transformed into the microwave conductivity $\sigma_{\mathrm{m}}=2 \pi f \varepsilon_{0} \varepsilon^{\prime \prime}$ (Figs. 4, 5). It is seen that the values of microwave conductivity of tested composites are higher by $4-5$ orders than the correspondent DC conductivities. This indicates high microwave loss in the material. Simultaneously, pure epoxy matrix also demonstrates distinct microwave loss due to its polymeric constituents. However, one does not need low-loss dielectric matrix for electromagnetic shielding composites. The obtained microwave conductivity values do not characterize the intrinsic microwave conductivity of nanotubes; it is the index of microwave loss in the mixture of dielectric/polymeric matrix and conductive nanocarbon filler. The intrinsic microwave conductivity of the filler in the above mixture could be derived by the effective medium theory [22], but it is still not developed for particles with high aspect ratio or complex shape.

The anisotropy $\sigma_{\mathrm{m}_{\mathrm{par}}} / \sigma_{\mathrm{m}_{\mathrm{per}}}$ of microwave conductivity of the measured oriented composites is much lower in comparison with DC measurements and varies between $\mathbf{1 . 2 6}$ and 2.04 for all tested concentrations and microwave frequencies. For instance, $\sigma_{\mathrm{m}_{\mathrm{par}}} / \sigma_{\mathrm{m}_{\mathrm{per}}}$ at $53.3 \mathrm{GHz}$ varies between 1.34 and 1.75 for MWCNTs concentration from 0.2 to $1.0 \%$. Pure epoxy manifests weak microwave anisotropy of 1.03 ; it can be caused by partial epoxy polymer chains alignment in the preferred direction under the electric field during the composite curing, or by nonideal composite mixture preparation.

Significant difference between measured DC and microwave conduc-

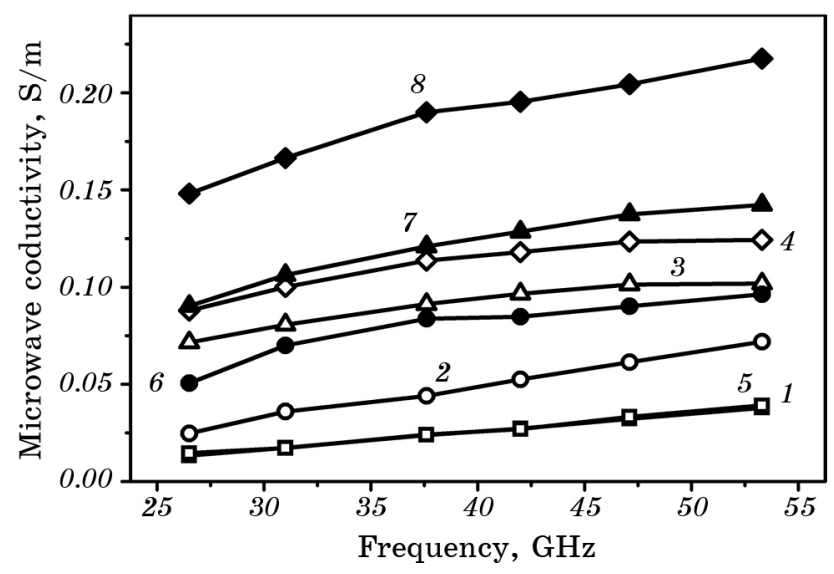

Fig. 4. Microwave conductivity $\sigma_{m}$ versus frequency for different MWCNTs orientation to the microwave electric field and different concentration: 1,2 , 3 , 4-perpendicular orientation and concentrations $0,0.2,0.4$ and $1.0 \%$ wt., respectively; $5,6,7,8$-parallel orientation and concentrations $0,0.2,0.4$ and $1.0 \%$ wt., respectively. 


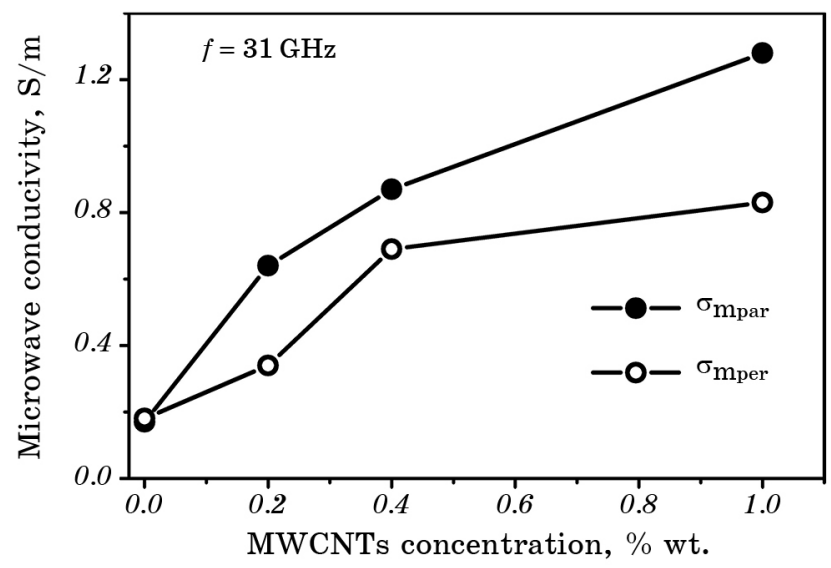

Fig. 5. Microwave conductivity $\sigma_{\mathrm{m}}$ versus MWCNTs content and orientation to the microwave electric field at frequency $f=31 \mathrm{GHz}: \sigma_{\mathrm{m}_{\mathrm{par}}}$-for parallel orientation of MWCNTs network to the test current, $\sigma_{\mathrm{m}_{\mathrm{per}}}-$ for perpendicular orientation of MWCNTs network.

tivity anisotropies can be attributed to the essential inequality of the actual electron travel under DC and microwave electric field. As compared with the charge migration in the case of DC measurements, microwave-alternating voltage generates almost infinitesimal charge displacement in the neighbourhood of its initial position. The mean charge displacement $s$ per half-cycle under the microwave electric field can be estimated as $2^{-1 / 2} \mu E_{0} /(2 f)$, where $\mu$ is the electron mobility in a MWCNT, $E_{0}$ is the maximum electric field in the waveguide, and $f$ is microwave frequency. The maximum electric field in the waveguide is calculated for dominant waveguide mode $H_{10}$ at the actual microwave power of $1 \mathrm{~mW}$ in the experiment.

Assuming the electron mobility $\mu \cong 10^{5} \mathrm{~cm}^{2} /(\mathrm{V} \cdot \mathrm{s})$ [23], the mean charge displacement per half-cycle was calculated: $s=15.5 \mathrm{~nm}$ at $f=53.3 \mathrm{GHz}$ and $s=28.5 \mathrm{~nm}$ at $f=26.5 \mathrm{GHz}$. Such magnitudes are upper estimates because of the used $E_{0}$ as the maximum value in the cross-section of the waveguide. While the transport in MWCNTs is found to be quasi-ballistic with mean free paths $<100 \mathrm{~nm}$ [24], the charge displacement in the tested frequency range is smaller than the mean free path and comparable with the MWCNT diameter. That is why the derived microwave composite conductivity exceeds considerably the corresponded DC conductivity values even at low MWCNTs concentrations. On the other hand, it means that the MWCNT aspect ratio is less significant as the limitation of possible microwave current direction in the MWCNTs network inside the composite. Direct headto-head contacts between nanotubes are also not important for micro- 
wave current. However, due to the shape of MWCNT, different orientation of nanotubes with respect to the microwave electric field vector provides different average volume current density in the composite. As the maximum current can flow on the element of cylinder in straight lines, the maximum conductivity and the maximum microwave loss is realized at the parallel orientation of MWCNTs and microwave electric field.

In this context, one can expect higher values of microwave conductivity anisotropy in oriented MWCNT/epoxy composites at lower frequencies, smaller nanotube diameters, and higher MWCNTs concentrations. The latter presupposes the use of epoxy resins with minimal viscosity and higher voltage for electric biasing during the composite curing.

Using the measured dielectric parameters of the tested composites, microwave absorptivity in the composite due to the dielectric loss was calculated (Fig. 6).

Data in Figure 6 are related to microwave propagation in compositefilled space nonmetering the impedance mismatch. The difference between attenuations for $1 \%$ wt. composites with parallel and perpendicularly oriented nanotubes varies from $0.38 \mathrm{~dB} / \mathrm{mm}$ at $26.5 \mathrm{GHz}$ to $0.68 \mathrm{~dB} / \mathrm{mm}$ at $53.3 \mathrm{GHz}$. As it was expected, the attenuation increases with MWCNTs concentration and microwave frequency. The absolute values of the measured attenuation are rather scant to apply the tested composites immediately as high-performance microwave shield, but it is conditioned by low filler concentrations used in this investigation. Increasing the concentration with simultaneous enhancement of

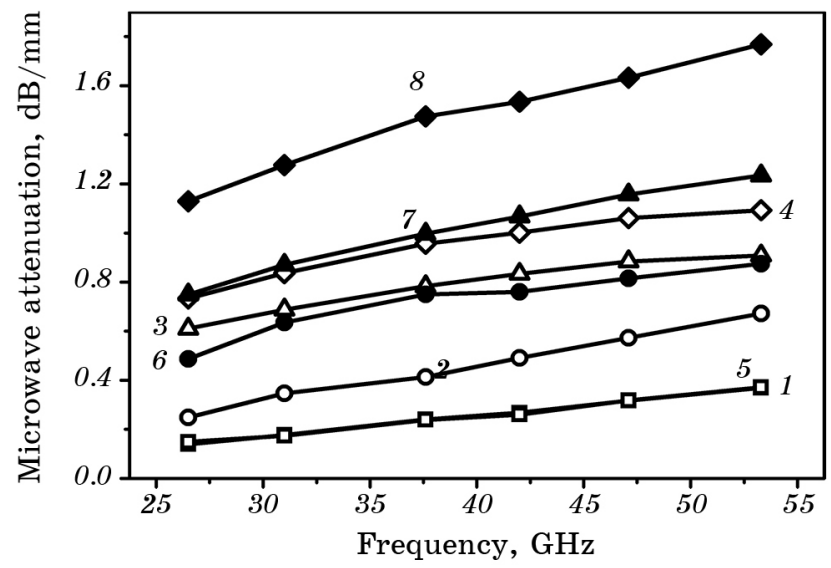

Fig. 6. Microwave absorptivity versus frequency in the MWCNT/epoxy composite for different MWCNTs orientation to the microwave electric field and different concentration: 1, 2, 3, 4-perpendicular orientation and concentrations $0,0.2,0.4$ and $1.0 \%$ wt., respectively; $5,6,7,8$-parallel orientation and concentrations $0,0.2,0.4$ and $1.0 \%$ wt., respectively. 
nanotubes orientation, one can realize drastic microwave attenuation increase [25] with the expected further improvement of polarization selectivity in the mentioned attenuation.

\section{CONCLUSIONS}

MWCNT/epoxy conductive composites were fabricated with oriented distribution of nanotubes induced by the AC electric field during the processing. The tested concentrations of $0.2-1.0 \% \mathrm{wt}$. were selected to provide both high degree of nanotubes ordering in the volume of epoxy composite matrix and considerable conductivity of the composite. This results in DC conductivity anisotropy as well as microwave conductivity anisotropy. Microwave conductivity of tested composites is higher by $4-5$ orders than the correspondent DC conductivity. On the contrary, DC conductivity anisotropy is 20 and more times higher than the correspondent microwave conductivity anisotropy. Such difference can be attributed to the essential inequality of the actual electron transport mechanisms under DC and microwave electric fields.

Acknowledgments: This research was partly supported by NATO No. UKR SFPP 984243 project.

\section{REFERENCES}

1. R. H. Friend, Conductive Polymers II: From Science to Applications (Shawbury: Rapra Technology Ltd.: 1993).

2. V. Erokhin, M. K. Ram, and Ö. Yavuz, The New Frontiers of Organic and Composite Nanotechnology (Oxford: Elsevier: 2011).

3. S. Maity, K. Singha, P. Debnath, and M. Singh, J. Safety Eng., 2: 11 (2013).

4. V. Udmale, D. Mishra, R. Gadhave, D. Pinjare, and R. Yamgar, Orient. J. Chem., 29: 927 (2013).

5. M. Chen, L. Zhang, S. Duan, S. Jing, H. Jiang, M. Luo, and C. Li, Nanoscale, 6: 3796 (2014).

6. J. Li, P. C. Ma, W. S. Chow, C. K. To, B. Z. Tang, and J.-K. Kim, Adv. Funct. Mater., 17: 3207 (2007).

7. J. Z. Kovacs, B. S. Velagala, K. Schulte, and W. Bauhofer, Compos. Sci. Technol., 67: 922 (2007).

8. D. S. Bychanok, M. V. Shuba, P. P. Kuzhir, S. A. Maksimenko, V. V. Kubarev, M. A. Kanygin, O. V. Sedelnikova, L. G. Bulusheva, and A. V. Okotrub, J.Appl. Phys., 114: 114304 (2013).

9. O. Malkina, H. Mahfuz, K. Sorge, A. Rondinone, J. Chen, K. More, S. Reeves, and V. Rangari, AIP Advances, 3: 042104 (2013).

10. A. I. Oliva-Avilés, F. Avilés, V. Sosa, A. I. Oliva, and F. Gamboa, Nanotechnology, 23: 465710 (2012).

11. M. Monti, M. Natali, L. Torre, and J. M. Kenny, Carbon, 50: 2453 (2012).

12. L. An and C. R. Friedrich, J.Appl. Phys., 105: 074314 (2009).

13. A. I. Oliva-Avilés, F. Avilés, V. Sosa, and G. D. Seidel, Carbon, 69: 342 (2014). 
14. M. S. Kumar, T. H. Kim, S. H. Lee, S. M. Song, J. W. Yang, K. S. Nahm, and E.-K. Suh, Chem. Phys. Lett., 383: 235 (2004).

15. R. Chan, C. Fung, and W. Li, Nanotechnology, 15: S672 (2004).

16. S.-J. Ma and W.-L. Guo, Chinese Phys. Lett., 25: 270 (2008).

17. Y.-F. Zhu, C. Ma, W. Zhang, R.-P. Zhang, N. Koratkar, and J. Liang, J. Appl. Phys., 105: 054319 (2009).

18. O. Yakovenko, L. Matzui, L. Vovchenko, and A. Zhuravkov, phys. status solidi (a), 211: 336 (2014).

19. L. F. Chen, C. K. Ong, C. P. Neo, V. V. Varadan, and V. K. Varadan, Microwave Electronics. Measurement and Materials Characterization (New York: Wiley: 2004).

20. M. Pozar, Microwave Engineering (Hoboken: Wiley: 2005).

21. Yu. S. Perets, L. Yu. Matzui, L. L. Vovchenko, Yu. I. Prylutskyy, P. Scharff, and U. Ritter, J. Mater. Sci., 49: 2098 (2014).

22. B. E. Springett, Phys. Rev. Lett., 31, Iss. 24: 1463 (1973).

23. J. H. Koo, Polymer Nanocomposites: Processing, Characterization, and Applications (New York: McGraw-Hill: 2006), p. 235.

24. M. Buitelaar, T. N. A. Bachtold, M. Iqbal, and C .Schonenberger, Phys. Rev. Lett., 88: 156801 (2002).

25. L. L. Vovchenko, V. V. Zagorodniy, L. Yu. Matzui, V. L. Launets, and V. V. Oliynyk, Proc. of $21^{\text {st }}$ International Crimean Conference 'CriMiCo Microwave and Telecommunication Technology' (September 12-16, 2011, Sevastopol, Ukraine), p. 775. 